\title{
899238
}

ESTIMATED PERFORMANCE AND FUTURE POTENTIAL OF SOLAR DYNAMIC AND PHOTOVOLTAIC POWER SYSTEMS FOR SELECTED LEO AND HEO MISSIONS

David J. Bents and Cheng Y. Lu

National Aeronautics and Space Administration

Lewis Research Center

Cleveland, Ohio 44135

SUMMARY

Solar PV and thermal dynamic power systems for application to selected LEO and HEO missions are characterized in the regime 7 to $35 \mathrm{kWe}$. Input parameters to the characterization are varied corresponding to anticipated introduction of improved or new technologies. Comparative assessment is made between the two power system types utilizing newly emerging technologies in cells and arrays. energy storage, optical surfaces, heat engines, thermal energy storage and thermal management.

The assessment is made to common ground rules and assumptions. The four missions (space station, Sun-synchronous, Van Allen belt and GEO) are representative of the anticipated range of multi-kilowatt Earth-orbit missions. System characterizations include all required subsystems,

o including power conditioning, cabling, and struc-

of ture, to deliver electrical power to the user.

Performance is estimated on the basis of three dif-

$\omega$ ferent levels of component technology: (1) state-of-art, (2) near-term, and (3) advanced technologies. These range from planar array silicon photovoltaics with IPV nickel hydrogen batteries and Brayton systems at $1000 \mathrm{~K}$ (state-of-art), to thin film GaAs solar cells with high energy density secondary batteries or regenerative fuel cells and $1300 \mathrm{~K}$ Stirling systems with ultralightweight concentrators and radiators (advanced). The system estimates inciude design margin for performance degradations from the known environmenta mechanisms (micrometeoroids and space debris. atomic oxygen. electron and proton $f(u x)$ which are modeled and applied depending on the mission.

The results give expected performance, mass and drag of multi-kilowatt Earth-orbiting solar power systems and show how overall system figure of merit will improve as new component technologies are incorporated. For example, aggressive development of supporting component technologies for solar dynamic power systems may result in a 3 to 1 improvement over 5OA. On the other hand, incorporation of improved cell and energy storage technologies into photovoltaic power systems may result in a 4 to 1 improvement. Although comparison between the two on the basis of mass and drag only is not the sole basis for power system selection, it is indicative of basic technological trends.
INTRODUCTION

Solar dynamic systems have long been recognized as a viable alternative to photovoltaic (PV) systems as a source of electrical power for spacecraft in Earth orbit. When compared to state-of-art (SOA) PV systems at mission power levels in the multikilowatt range, the solar dynamic system designs have higher collector and conversion efficiencies than PV systems, leading to reduced weight and drag [1]. Much of this advantage has to do with dynamic system's use of concentration to produce a high temperature heat source that can drive a heat engine at higher conversion efficiencies than the solar cells flown to date.

There are also theoretical advantages that have to do with the storage of energy for the dark side portion of the orbit which in LEO accounts for roughly one-third of the cycle. The PV System must collect, convert and store all the energy required for the darkside period as electrical energy, which requires a storage medium that is relatively heavy and inefficient. The collector and power conversion must both be oversized in order to collect this energy during the sunlit portion. On the other hand the solar dynamic (SD) system stores its darkside energy as heat which is contained in a much more energy-dense medium (302 W-hr/kg for lithium fluoride thermal storage versus 10 to $50 \mathrm{~W}-\mathrm{hr} / \mathrm{kg}$ for secondary batteries). The SD system then performs conversion to electrical power continuously during the entire orbit so that only the collector has to be oversized; the converter (heat engine and radiator) does not.

Despite these advantages solar dynamic systems were never developed for space use. Funding for SO development was curtailed in 1970 because anticipated power requirements for the remaining missions (typically less than $1 \mathrm{kWe}$ ) were too low for these advantages to be effectively exploited; as a result photovoltaics have been the solar power system of choice for all missions flown to date. With the anticipated increase in power requirements for space station missions and beyond, however, the advantages of solar dynamic systems are again being explored.

U.S. Government work not protected by U.S. copyright. 
To bring space solar dynamics to fruition, several different component technologies must be concurrently developed. There are programs underway to accomplish this. In addition to the solar dynamic power module development effort for space station, advanced concentrator and heat receiver technology is being developed for higher temperature Brayton and Stirling systems (the Brayton conversion is considered to be mature technology while the Stirling is in advanced development stage). If adequate funding for these programs is continued. verification of advanced concentrator and heat receiver components could be expected in the 1993-94 timeframe. Successful development of these components should lead to a space power system with unique capabilities, well suited to capture some of the future high power space missions that are contemplated.

To see where the state of SD technology may progress if these components can be successfully developed, it is useful to consider its competitive potential vis a vis the more well established PV systems, considering the overall system improvements to each that may result if new or improved component technologies become available. To do this, a study was performed to characterize both solar PV and thermal dynamic power systems as competitors with respect to their mass and drag area. Mass and drag area are not the only attributes to be considered in selection of power systems for space use; but they are important discriminators.

Four near-Earth orbit missions, representative of multikilowatt-electric missions anticipated for the post 1990 timeframe, were chosen. They ranged from space station in LEO to a military mission in the Van Allen Belt (Table I). Typically LEO missions encounter higher drag, where solar dynamic systems should hold an advantage due to reduced collector area resulting from their higher overall conversion efficiency. Van Allen Belt missions should also favor solar dynamic systems due to their inherent insensitivity to radiation which degrades the PV's. On the other hand the Sunsynchronous mission, which has no darkside period, should favor the PV's instead since no energy.storage is required.

With the mission requirements established, solar dynamic and photovoltaic power system conceptual designs were generated for each mission on the basis of the major system components:

Solar Dynamics

Concentrator

Heat receiver and thermal energy storage

Power conversion (heat engine and alternator)

Heat rejection (radiator)

structure and electrical hardware

Photovoltaic systems

Photovoltaic array

Energy storage

Heat rejection

Structure and electrical hardware which were characterized to individual figures of merit based on component technology developments reported in the literature. Figures of merit for solar dynamic components would include solar concentrator kilograms per square meter, heat receiver and heat engine kilograms per kilowatt, radiator kilograms per square meter and so on; for photovoltaic systems it would be parameters such as electrical watts per square meter of solar array blanket, energy storage watt-hours per kilogram and so forth.

For the missions of interest, SD and PV power system designs were generated to meet the mission requirements, assuming physical configurations according to Figs. 1 and 2 for solar dynamic and photovoltaic systems respectively. Each design was optimized for that particular mission, taking into account various performance and degradation factors associated with length of mission and exposure to orbital and environmental effects which affect performance, or must be compensated for by additional mass. These effects would include the performance variation as operating temperature is varied over the orbit (Fig. 3) due to solar exposure, Earth albedo, and solar cell output power degradation from exposure to the space radiation environment ( $F i g .4$ ). For example, Fig. 5 shows how array radiation exposure and degradation over 7 years exposure can be reduced by increasing coverglass thickness to forestall radiation degradation. Increasing the thickness reduces the degradation leading to less power loss at end of life, but at the expense of increasing array mass. Fig. 6 shows the optimum coverglass thickness for that tradeoff applied to mission 4 . Table II summarizes the orbit environmental effects that were considered.

The system components were characterized at three levels of technology according to the following definitions.

\section{Space Station Era}

The current state-of-art; roughly equivalent to NASA technology levels 7 to 9 . Systems are well described in the space station documents and other references. Hardware development programs are in place. Supporting technologies are available now (approximately 1985 technology) and flight hardware would be available according to the space station development schedule. The space station era solar dynamic systems considered were the $1000 \mathrm{~K}$ closed Brayton cycle (CBC) and $700 \mathrm{~K}$ organic Rankine cycle (ORC) systems, employing pumped loop or heat pipe radiators for heat rejection [3]. Space station era PV systems were planar silicon (Si) arrays combined with IPV nickel hydrogen ( $\mathrm{NiH}$ ) batteries for energy storage [4].

\section{Near Term}

Considered equivalent to NASA technology

levels 6 to 8 . System characterizations are based 
on supporting technology believed to be available by 1993 to 1995 with some development. Performance of critical hardware components has been demonstrated, component technologies and systems are described in the literature, reports or papers have been published. The component technologies considered to be near term for SO would be CBC at $1100 \mathrm{~K}$ inlet or free piston Stirling (FPSE) at $1050 \mathrm{~K}$ combined with a heat pipe radiator [5]; the overall improvement for SO would come about mainly through increases in temperature. The near term PV system would typically be a lightweight planer Si array incorporating APSA technology [6] or a multiconcentrator GaAs array (MCPV) combined with improved IPV nickel hydrogen battery [7] or alkaline regenerative fuel cell (ARFC) for energy storage. The APSA is an advanced planar silicon array greatly reduced in weight; the MCPV array uses GaAs cells, which are more efficient than Si so that orbital drag is reduced.

\section{Advanced}

Current state of development roughly equivalent to NASA technology levels 2 to 5 . System characterizations are based on supporting technology that would be available if all goals of the technology development programs are realized. Technology could be available as early as FY2000 given adequate resources - "Proposals in hand." The advanced solar dynamic systems would incorporate ultralightweight $\left(2 \mathrm{~kg} / \mathrm{m}^{2}\right)$ concentrators [8] and receivers [9] utilizing Mg2Si PCM thermal storage and employ either CBC or FPSE conversion at 1350 and $1300 \mathrm{~K}$ respectively. Heat rejection would be in the form of an advanced radiator such as the liquid droplet or moving belt radiator [10].

Advanced photovoltaic systems would be characterized by ultralightweight arrays utilizing high efficiency cells $[11,12]$ in conjunction with high temperature sodium sulfur batteries [7] or advanced regenerative fuel celis [13].

The component figures of merit as a function of technology timeframe for solar dynamic systems are summarized in Table III. The photovoltaic systems are likewise summarized in Table IV.

When a competitive assessment is made it is important that the various technology levels are strictly defined. A common mistake is to compare something that has not been developed yet to existing state-of-art. To ensure impartial comparison within the mission regime, a common set of ground rules and assumptions was applied to the designs, namely:

(1) Power system mass estimates include al components necessary to deliver electrical power to a common bussbar. The SD systems included all of the support structure, gimbals, fine pointing mechanism and hardware required to mount them to the spacecraft and track the Sun independent of spacecraft attitude. On the other hand, power conditioning was limited to a frequency changer to put it on a common footing with the PV system. For PV systems there was included, in addition to the PV array itself, all of the mast, joints, structure, electrical leads and wiring harness, blanket box, roll rings, all of the power conditioning associated with charge and discharge of the battery, and an inverter. However, thermal management of the electronic equipment was not included for either SD or PV.

(2) The power systems were specified to deliver the same form of electrical power to the bussbar. Twenty kilohertz single phase ac was selected since it is appropriate for multikilowattelectric power but yields no inherent integration advantage to either dynamic systems (low-frequency, high voltage $\mathrm{ac}$ ) or PV/battery systems (low voltage $d c$ ). Parts of Power Management and Distribution (PMAD) downstream of the bussbar, which would be common to both systems, were excluded.

(3) All the contingency, excess, redundancy and safety factors in reported component figures of merit were eliminated. For example, if a reported solar dynamic design used dual PCU's for redundancy, the study characterization based the converter weight on only one unit.

(4) Orbital drag was time averaged taking into account changes in frontal area with sun orientation during the orbit period. The space environment and orbital parameters were defined at nominal conditions. For example, Fig. 7 shows the atmospheric density that was assumed for missions 1 and 2 ; Fig. 8 shows the trapped electron and proton environment that was applied to mission 3 photovoltaic arrays.

\section{RESULTS}

The result of this study was two families of system conceptual designs to fill the matrix of cases given in Table $V$. Each system design resulted in a component mass breakdown and estimates of overall characteristics including total system mass. The total system mass would be not only the mass of all component hardware previously described, but also the mass of makeup propellant needed to overcome orbital drag during the mission (a thruster specific impulse of $200 \mathrm{sec}$ was assumed).

Table VI(a) summarizes the results for space station era technologies applied to mission 1 (the space station mission). The first column contains the estimated mass of all system hardware (with or without the cable tray and truss structures), followed by specific power in watts delivered per system kilogram. Not surprisingly, results mirror the space station design description [14].

The last column in the table indicates the mass of propellant required for drag makeup.

Although the hardware weights of these space station era systems are roughly equivalent, the solar dynamic system's reduced drag area results in lower overall mass than photovoltaics. For LEO missions, orbital drag discriminates against power systems with low collector efficiency.

Considering the future growth space station (mission 2) Table VI(b) gives results for near 
term, and advanced technology characterizations. In the near term, introduction of APSA technology will significantly reduce the weight of planar silicon arrays to where hardware weight of the PV system will be less than solar dynamics. However, because collector efficiency is lower. its greater drag negates the hardware weight advantage at reduced altitudes. On the other hand the MCPV, which employs high efficiency GaAs cells and has less drag, is approximately as heavy as the solar dynamic systems.

Use of a higher specific impulse thruster, such as an arcjet or ion thruster, would reduce the drag makeup penalty for both photovoltaic and solar dynamic systems. Shorter missions and higher altitudes also reduce the mass of propellant required.

When advanced technologies are considered, the photovoltaic system weight drops again mainly due to introduction of higher density energy storage (sodium-sulfur battery). With the introduction of high efficiency cells that are also light in weight (GaAs cells made by the cleft process) to the improved APSA array, drag area is also reduced. At this point the drag makeup penalty is about the same for both systems, and the mass and drag advantage of solar dynamics over the PV's appears to be lost.

Table VI(c) shows system totals for the Van Allen Belt mission. The PV system hardware mass is less than the equivalent solar dynamic system even though the array penalties due to radiation degradation in this orbit have been taken into account. That is mainly because less energy storage is required since the darkside fraction of orbit for this mission is less than in LEO. Solar dynamic systems do not appear competitive for this mission. The greater drag area of the PV systems are not a significant penalty here because altitude is high enough that orbital drag is negligible.

Table VI(d) gives results for the Sunsynchronous mission. The altitude is still high enough that drag, although not negligible, is small. On a mass basis for all three technology levels considered, solar dynamic systems have no apparent advantage over photovoltaic systems for this mission because no dark period energy storage is needed.

\section{CONCLUSIONS}

If all of the required component technologies for solar dynamic systems are developed as projected, their mass and drag advantage over photovoltaic systems will be maintained only at low altitudes where orbital drag and shade period is appreciable. This advantage is eroding as new PV and battery technologies are introduced.

Figure 9 summarizes how solar dynamic systems for LEO (mission 2) could be improved over SOA through realization of advanced component technologies in the near term and beyond. In the near term, the CBC would improve as a result of nigher inlet temperatures, and adoption of the FPSE could yield an additional improvement over that, due to the Stirling's flatter heat rejection characteristic (requires less radiator area). However, the greatest overall improvement could be made by development of the advanced concentrator and heat receiver, which is applicable to both $C B C$ and Stirling. Ultimately solar dynamic system performance is not limited by engine high temperature capacity but the ability of the concentrator/ receiver to achieve that temperature.

Looking forward to further advanced technologies the concentrator may be reduced in weight by a factor of three or more, and the radiator by a factor of two or more from SOA. Based on the data presented herein, the overall development payoff that could result would be approximately threefold.

However, the photovoltaic systems for these missions will unquestionably be improved over the same time periods ( $F i g .10$ ) since their component technologies also have development programs in place, exceeding the expenditure for SD component development by more than 10 to 1. Based on the study data, the overall development payoff for $P V$ applied to multi-kilowatt LEO inissions appears to be a fourfold reduction in system hardware weight.

Competitive characterization of space power systems which have not been developed yet is at best a speculative effort. The foregoing comparison is a prediction based on anticipated future development, and is made only on the basis of system mass and drag. While it is indicative of technological trends it does not represent all of the criteria for power system selection. There are other important attributes, including but not $1 \mathrm{im-}$ ited to: life cycle costs, system reliability, graceful degradation response to failure, ease of spacecraft integration and (for military mission) survivability to hostile threats which may take precedence over mass and drag, depending on the specifics of the mission. When these other attributes (such as radiation hardness) are considered. there may be missions whose requirements are more uniquely suited to solar dynamics, (near-sun or military missions) or may yield advantages beyond the scope of this comparison - therefore, both technologies will continue to be pursued at the present time.

\section{REFERENCES}

1. M.0. Dustin, J.M. Savino, D.E. Lacy, R.P. Migra, A.J. Juhasz, and C.E. Coles, "Advanced Solar Dynamic Space Power Systems Perspectives, Requirements and Technology Needs," NASA TM-88884, 1987

2. P.A. Iles, "Space Solar Cells - The Moving Target," Proceedings of the 23rd Intersociety Energy Conversion Engineering Conference Vol. 3, IEEE, Piscataway, NJ, 1988, pp. 75-78. 
3. R.V. Boyle, M.G. Coombs, and C.T. Kudija, "Solar Dynamic Power Option for the Space Station," Proceedings of the 23rd Intersociety Energy Conversion Engineering Conference, Vol. 3, IEEE, Piscataway, NJ, 1988 , pp. 319-328.

4. J.W. Dunning Jr., "Space Station Power System Requirements," Proceedings of the 23rd Intersociety Energy Conversion Engineering Conference, Vol. 3, IEEE, Piscataway, NJ, 1988, pp. 29-36.

5. W.E. Wallin, and M.O. Dustin, "Advanced Space Solar Dynamic Power Systems Beyond IOC Space Station," Energy - New Frontiers (22nd IECEC). Vol. 1, AIAA, New York, 1987, Pp. 145-155.

6. R. Kurland and P. Stella, "Advanced Photovoltaic Solar Array Design," Energy - New Frontiers (22nd IECEC), Vol. 1, AIAA, New York, 1987 , pp. 103-114.

7. A.H. Zimmerman, and D.M. Speckman, "High Energy Density Rechargeable Batteries for Aerospace Power Requirements," Aerospace Corporation Report No. SD-TR-87-43, El Segundo, CA, Aug. 1987. (Avail. NTIS, $A D-A 184883$ ).

8. R.D. Corrigan, and D.T. Ehresman, "Solar Concentrator Advanced Development Project, Energy - New Frontiers (22nd IECEC), Vol. 1 AIAA, New York, 1987, pp. 156-161.
9. H.J. Stumpf, M.G. Coombs, and D.E. Lacy, "Advanced Space Solar Dynamic Receivers," Proceedings of the 23 rd Intersociety Energy Conversion Engineering Conference, Vol. 3, ASME, New York, 1988, pp. 357-365.

10. K.A. White III, "Moving Belt Radiator Technology Issues, "Proceedings of the 23rd Intersociety Energy Conversion Engineering Conference, Vol. 1, ASME, New York, 1988, pp. 365-372.

11. M.W. Mills and R.M. Kurland, "The Impact of Solar Cell Technology on Planar Solar Array Performance," Space Photovoltaic Research and Technology 1988, NASA CP-3030, 1988, pp. 111-121.

12. S.P. Tobin, et al., "A 23.7 Percent Efficient One-Sun GaAs Solar Cell," Nineteenth IEEE Photovoltaic Specialists Conference, IEEE. Piscataway, NJ, 1987, pp. 1492-1493.

13. R.K. Taenaka, E. Adler, E.J. Stofel, and K.B. Clark "Regenerative Fuel Cell Systems for Mid-to-High Orbit Satellites," Energy - New Frontiers (22nd IECEC), Vol. 4, AIAA, New York, 1987, pp. 2016-2021.

14. "Space Station Power System," NASA Lewis Research Center, Description Document.

TABLE I. - MISSION DEFINITION

\begin{tabular}{|c|c|c|c|c|c|c|}
\hline Missiona & $\begin{array}{c}\text { Power, } \\
\mathrm{kw}\end{array}$ & $\begin{array}{c}\text { Altitude, } \\
\mathrm{km}\end{array}$ & $\begin{array}{c}\text { Inclination, } \\
\mathrm{deg}\end{array}$ & $\begin{array}{c}\text { Sun/eclipse, } \\
\mathrm{min}\end{array}$ & $\begin{array}{c}\text { Compare } \\
\text { at years } \\
\text { dfter BOL }\end{array}$ & Application \\
\hline 1 & 25 & 334 & 28.5 & $54.76 / 36.38$ & 3 & $\begin{array}{c}\text { Space station } \\
\text { (minimum altitude } \\
\text { maximum drag) } \\
\text { Growth space } \\
\text { station } \\
3\end{array}$ \\
35 & 500 & 28.5 & $58.75 / 35.68$ & 7 & 7 & $\begin{array}{c}\text { Van Allen belt } \\
\text { (military mission) } \\
\text { Sun-synchronous } \\
\text { Earth observation }\end{array}$ \\
\hline
\end{tabular}

aSelected missions 1, 2, and 3 are where solar dynamics usually appear competitive with photovoltaics. 
TABLE II. - SPACE ENVIRONMENTAL EFFECTS

\begin{tabular}{|c|c|c|}
\hline Environment & Major function & Effects \\
\hline $\begin{array}{l}\text { Space sink temperature } \\
\text { Earth albedo } \\
\text { Solar insolation } \\
\text { Earth shine }\end{array}$ & Position of spacecraft & $\begin{array}{l}\text { Radiator design; } \\
\text { photovoltaic } \\
\text { operating temperature }\end{array}$ \\
\hline $\begin{array}{l}\text { Radiation (trapped electron } \\
\text { and proton and solar flare } \\
\text { proton) }\end{array}$ & $\begin{array}{l}\text { Position of spacecraft, } \\
\text { Epoch }\end{array}$ & Solar cell degradation \\
\hline Atmospheric density & $\begin{array}{l}\text { Position and orientation } \\
\text { of spacecraft, } \\
\text { Epoch }\end{array}$ & Drag \\
\hline Atomic oxygen & $\begin{array}{l}\text { Position of spacecraft, } \\
\text { Epoch }\end{array}$ & Surface recession \\
\hline Meteoroids and debris & $\begin{array}{l}\text { Position of spacecraft, } \\
\text { Epoch }\end{array}$ & Reliability \\
\hline
\end{tabular}

TABLE III. - DEFINITION OF SOLAR DYNAMIC TECHNOLOGIES

\begin{tabular}{|c|c|c|c|c|c|c|}
\hline \multirow[t]{6}{*}{ Characteristic } & \multicolumn{6}{|c|}{ Technology level } \\
\hline & \multicolumn{2}{|c|}{$\begin{array}{c}\text { Space } \\
\text { station }\end{array}$} & \multicolumn{2}{|c|}{$\begin{array}{l}\text { Near } \\
\text { term }\end{array}$} & \multicolumn{2}{|c|}{ Advanced } \\
\hline & \multicolumn{6}{|c|}{ Power-conditioning unit } \\
\hline & ORC & CBC & $\mathrm{CBC}$ & FPSE & $\mathrm{CBC}$ & FPSE \\
\hline & \multicolumn{6}{|c|}{ Thermal energy storage } \\
\hline & $\mathrm{LiOH}$ & Lif-CaF & \multicolumn{2}{|c|}{ LiF } & \multicolumn{2}{|c|}{$\mathrm{Mg}_{2} \mathrm{Si}$} \\
\hline $\begin{array}{l}\text { Specific mass of concentrator, } \\
\mathrm{kg} / \mathrm{m}^{2} \text { ( } \mathrm{fine-pointing} \mathrm{mechanism} \\
\text { included) }\end{array}$ & 7 & 8 & 7 & 7 & 2 & 2 \\
\hline Receiver + TES efficiency, percent & 90 & 89 & 92 & 92 & 95 & 95 \\
\hline Specific mass of receiver, $\mathrm{kg} / \mathrm{kWt}$ & 2.9 & 3.8 & 3.3 & 3 & -- & -- \\
\hline Specific mass of TES, $\mathrm{kg} / \mathrm{kW}-\mathrm{hr}$ & 12 & 18 & 9 & 9 & -- & -- \\
\hline Specific mass of receiver + TES, $\mathrm{kg} / \mathrm{kW}$ & --- & --- & -- & -- & 22 & 17 \\
\hline PCU efficiency, percent & 27 & 33 & 36 & 41 & 40 & $\begin{array}{r}45 \\
5\end{array}$ \\
\hline Specific mass of $\mathrm{PCU}, \mathrm{kg} / \mathrm{kW}$ & 24 & 29 & 24 & 16 & 14 & 5 \\
\hline $\begin{array}{l}\text { Specific mass of radiator, } \mathrm{kg} / \mathrm{m}^{2} \\
\text { Frequency converter efficiency, }\end{array}$ & 12.4 & 8.5 & 7 & 7.3 & 2 & 2 \\
\hline percent & 93 & 93 & 93 & 93 & 96 & 96 \\
\hline Specific mass of BOP, a $\mathrm{kg} / \mathrm{kW}$ & 60 & 61 & 55 & 55 & 46 & 46 \\
\hline
\end{tabular}

Interface structure, beta gimbal, electrical equipment, and integration hardware. 
TABLE IV. - DEFINITION OF PHOTOVOLTAIC TECHNOLOGIES

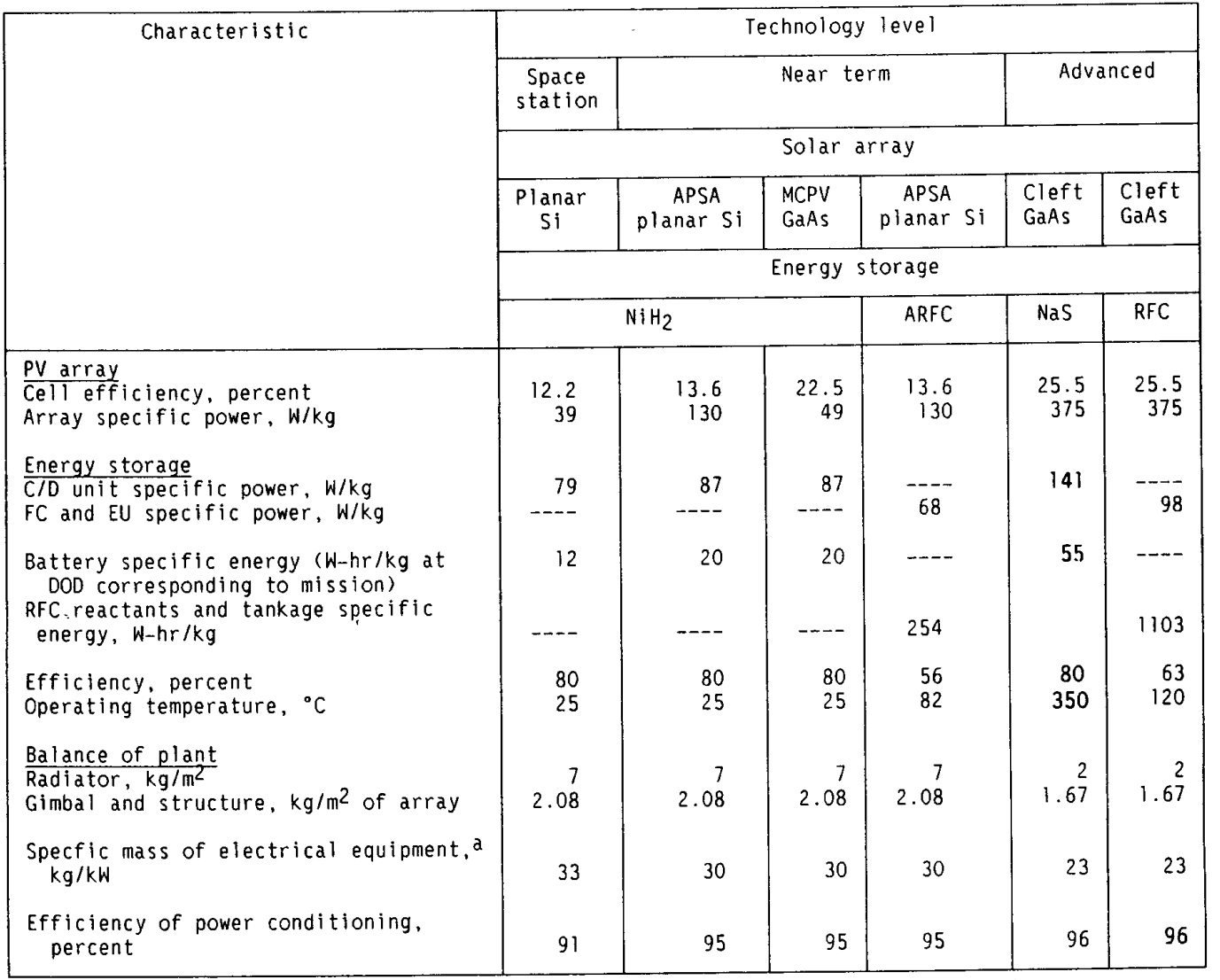

apV source controller, $d c / a c$ inverter, $a c$ and $d c$ switching units, cable trays, and electrical equipment cable set.

TABLE V. - MATRIX OF CASES

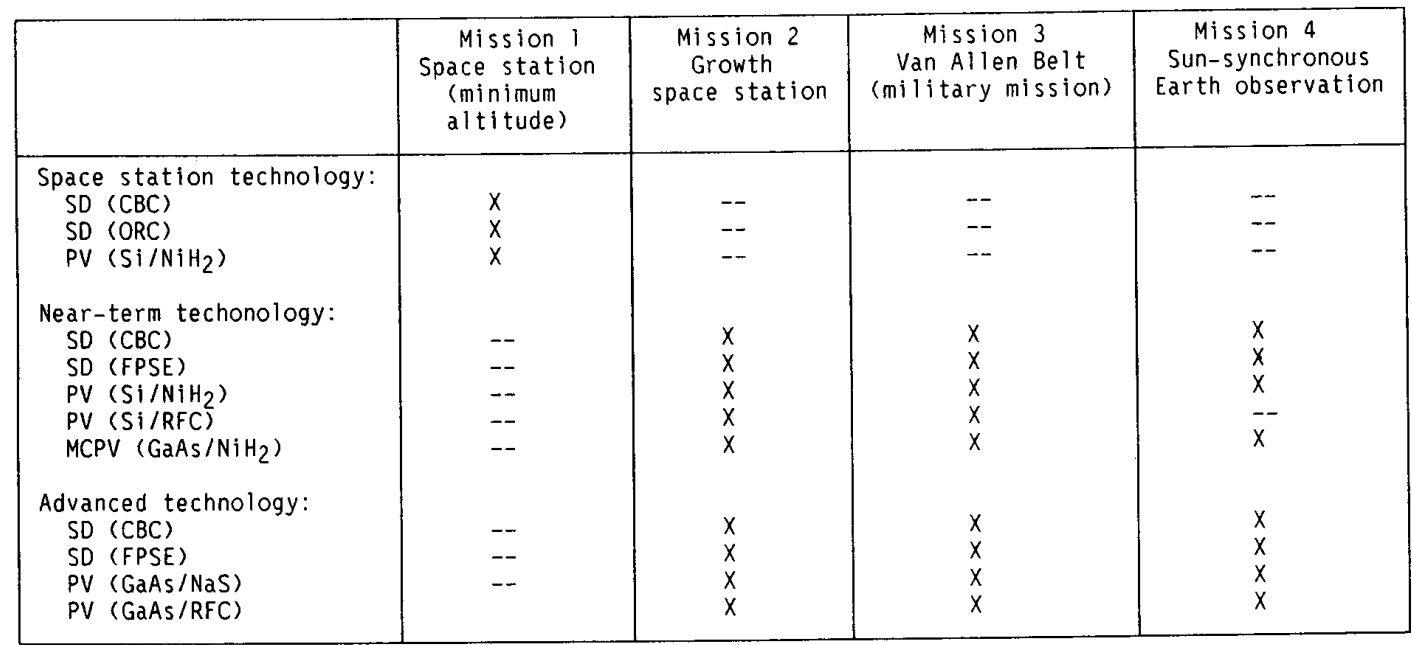


TABLE VI. - POWER SYSTEMS

(a) Space station era (state of the art) - mission 1

\begin{tabular}{|l|c|c|c|c|}
\hline & $\begin{array}{c}\text { System } \\
\text { hardware } \\
\text { weight, } \\
\mathrm{kg}\end{array}$ & $\begin{array}{c}\text { Specific } \\
\text { power, } \\
\mathrm{W} / \mathrm{kg}\end{array}$ & $\begin{array}{c}\text { Total } \\
\text { drag area, } \\
\mathrm{m}^{2}\end{array}$ & $\begin{array}{c}\text { Propel lant } \\
\text { needed, } \\
\mathrm{kg}\end{array}$ \\
\hline Solar dynamic (ORC) & $\begin{array}{c}5953 \\
(5211)\end{array}$ & $\begin{array}{c}4.20 \\
(4.80)\end{array}$ & 155.08 & 4668 \\
Solar dynamic (CBC) & $\begin{array}{c}5933 \\
(5191)\end{array}$ & $\begin{array}{c}4.21 \\
(4.82)\end{array}$ & 128.61 & 387 \\
Photovoltaic (Si/NiH2) & $\begin{array}{c}5760 \\
(5425)\end{array}$ & $\begin{array}{c}4.34 \\
(4.61)\end{array}$ & 359.06 & 10807 \\
\hline
\end{tabular}

(b) Near term and advanced - mission 2

\begin{tabular}{|c|c|c|c|c|}
\hline \multicolumn{5}{|c|}{ Near term } \\
\hline Solar dynamic (CBC) & $\begin{array}{c}6800 \\
(5865)\end{array}$ & $\begin{array}{c}5.15 \\
(5.97)\end{array}$ & 154.72 & 555 \\
\hline Solar dynamic (FPSE) & $\begin{array}{c}5489 \\
(4554)\end{array}$ & $\begin{array}{c}6.38 \\
(7.69)\end{array}$ & 128.63 & 462 \\
\hline Photovoltaic ( $\mathrm{Si} / \mathrm{NiH} 2)$ & $\begin{array}{c}4890 \\
(4509)\end{array}$ & $\begin{array}{l}7.16 \\
(7.76)\end{array}$ & 374.95 & 1346 \\
\hline Photovoltaic (Si/ARFC) & $\begin{array}{c}4066 \\
(3669)\end{array}$ & $\begin{array}{c}8.61 \\
(9.54)\end{array}$ & 409.83 & 1471 \\
\hline Photovoltaic (MCPV/NiHz) & $\begin{array}{c}6076 \\
(5741)\end{array}$ & $\begin{array}{c}5.76 \\
(6.10)\end{array}$ & 247.01 & 887 \\
\hline \multicolumn{5}{|c|}{ Advanced } \\
\hline Solar dynamic (CBC) & $\begin{array}{c}3465 \\
(2686)\end{array}$ & $\begin{array}{c}10.1 \\
(13.03)\end{array}$ & 109.13 & 392 \\
\hline Solar dynamic (FPSE) & $\begin{array}{c}2824 \\
(2045)\end{array}$ & $\begin{array}{c}12.39 \\
(17.11)\end{array}$ & 93.92 & 337 \\
\hline Photovoltaic (GaAs/NaS) & $\begin{array}{c}2118 \\
(1879)\end{array}$ & $\begin{array}{c}16.53 \\
(18.63)\end{array}$ & 151.82 & 542 \\
\hline Photovoltaic (GaAs/ARFC) & $\begin{array}{c}1949 \\
(1707)\end{array}$ & $\begin{array}{c}17.96 \\
(20.50)\end{array}$ & 169.55 & 689 \\
\hline
\end{tabular}

anumber in parenthesis is mass of system without integration hardware

(cable trays and truss).

bspecific impluse of $200 \mathrm{sec}$ assumed for drag makeup thruster. 
TABLE VI. - Concluded.

(c) Near term and advanced - mission 3

\begin{tabular}{|c|c|c|c|c|}
\hline & $\begin{array}{c}\text { System } \\
\text { hardware } \\
\text { weight, } \\
\mathrm{kg}\end{array}$ & $\begin{array}{c}\text { Specific } \\
\text { power, } \\
\text { W/kg }\end{array}$ & $\begin{array}{c}\text { Total } \\
\text { drag } m^{2}\end{array}$ & $\begin{array}{c}\text { Prope llant } \\
\text { needed, } \\
\mathrm{kg}\end{array}$ \\
\hline \multicolumn{5}{|c|}{ Near term } \\
\hline Solar dynamic (CBC) & $\begin{array}{c}1507 \\
(1320)\end{array}$ & $\begin{array}{c}4.64 \\
(5.30)\end{array}$ & 29.58 & -- \\
\hline Solar dynamic (FPSE) & $\begin{array}{c}1242 \\
(1055)\end{array}$ & $\begin{array}{c}5.64 \\
(6.64)\end{array}$ & 25.17 & -- \\
\hline Photovoltaic $\left(\mathrm{Si} / \mathrm{NiH}_{2}\right)$ & $\begin{array}{l}1034 \\
(952)\end{array}$ & $\begin{array}{c}6.77 \\
(7.35)\end{array}$ & 89.50 & -- \\
\hline Photovoltaic (Si/ARFC) & $\begin{array}{c}991 \\
\langle 906\rangle\end{array}$ & $\begin{array}{c}7.06 \\
(7.73)\end{array}$ & 96.88 & -- \\
\hline Photovoltaic $\left(\mathrm{MCPV} / \mathrm{NiH}_{2}\right)$ & $\begin{array}{c}1146 \\
(1080)\end{array}$ & $\begin{array}{c}6.11 \\
(6.48)\end{array}$ & 46.52 & -- \\
\hline \multicolumn{5}{|c|}{ Advanced } \\
\hline Solar dynamic (CBC) & $\begin{array}{c}688 \\
(532)\end{array}$ & $\begin{array}{c}10.17 \\
(13.16)\end{array}$ & 19.79 & -- \\
\hline Solar dynamic (FPSE) & $\begin{array}{c}561 \\
(405)\end{array}$ & $\begin{array}{c}12.48 \\
(17.28)\end{array}$ & 17.30 & -- \\
\hline Photovoltaic (GaAs/NaS) & $\begin{array}{c}434 \\
(385)\end{array}$ & $\begin{array}{c}16.13 \\
(18.18)\end{array}$ & 33.52 & -- \\
\hline Photovoltaic (GaAs/ARFC) & $\begin{array}{l}499.2 \\
(450)\end{array}$ & $\begin{array}{c}14.02 \\
(15.56)\end{array}$ & 37.12 & -- \\
\hline
\end{tabular}

(d) Near term and advanced - mission 4

\begin{tabular}{|c|c|c|c|c|}
\hline \multicolumn{5}{|c|}{ Near term } \\
\hline Solar dynamic (CBC) & $\begin{array}{c}1712 \\
(1445)\end{array}$ & $\begin{array}{c}5.84 \\
(6.92)\end{array}$ & 28.91 & 6 \\
\hline Solar dynamic (FPSE) & $\begin{array}{c}1333 \\
(1866)\end{array}$ & $\begin{array}{c}7.50 \\
(9.38)\end{array}$ & 23.31 & 5 \\
\hline Photovoltaic (Si) & $\begin{array}{c}621 \\
(528)\end{array}$ & $\begin{array}{c}16.10 \\
(18.94)\end{array}$ & 58.17 & 12 \\
\hline Photovoltaic (MCPV) & $\begin{array}{c}782 \\
(697) .\end{array}$ & $\begin{array}{c}12.79 \\
(14.35)\end{array}$ & 35.62 & 8 \\
\hline \multicolumn{5}{|c|}{ Advanced } \\
\hline Solar dynamic (CBC) & $\begin{array}{c}826 \\
(604)\end{array}$ & $\begin{array}{c}12.11 \\
(16.56)\end{array}$ & 20.55 & 4 \\
\hline Solar dynamic (FPSE) & $\begin{array}{c}671 \\
(448)\end{array}$ & $\begin{array}{c}14.90 \\
(22.32)\end{array}$ & 17.41 & 4 \\
\hline Photovoltaic (GaAs) & $\begin{array}{c}347 \\
(285)\end{array}$ & $\begin{array}{l}28.82 \\
35.14\end{array}$ & 24.62 & 5 \\
\hline
\end{tabular}

a Number in parenthesis is mass of system without integration hardware cable trays and truss).

bspecific impluse of $200 \mathrm{sec}$ assumed for drag makeup thruster. 


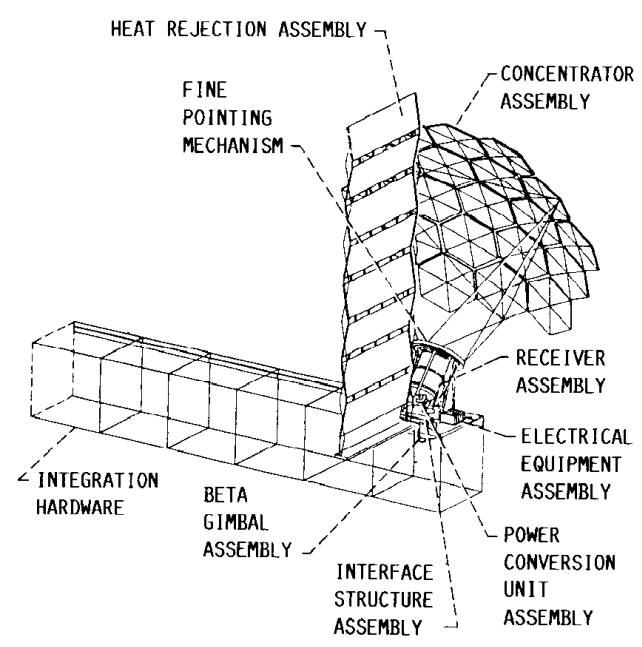

FIGURE 1. - SD CBC MODULE CONFIGURATION.

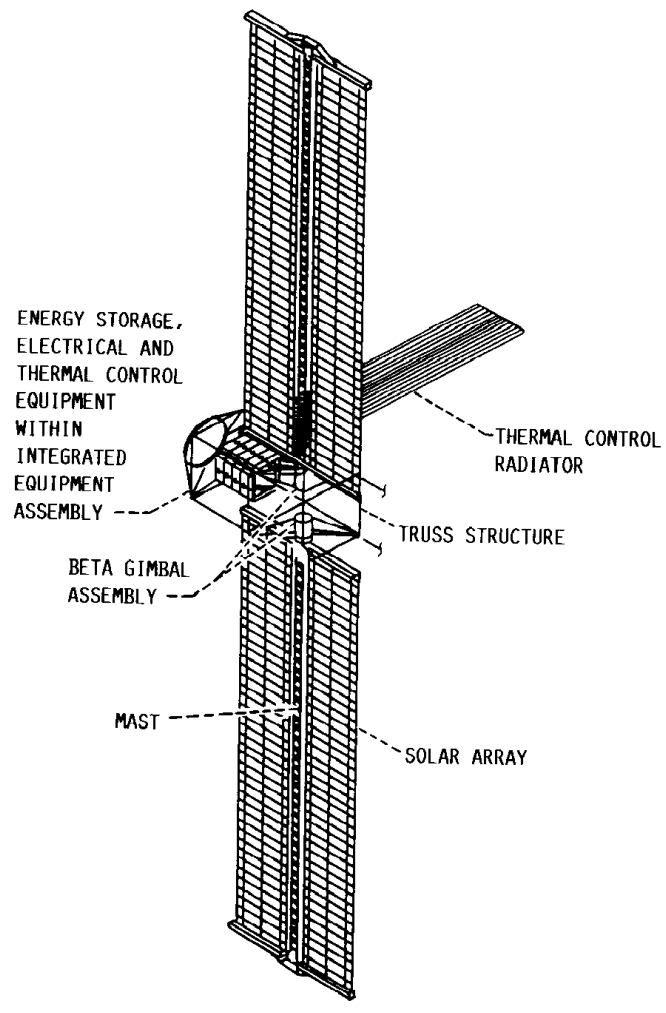

FIGURE 2. - PV MODULE CONFIGURATION.

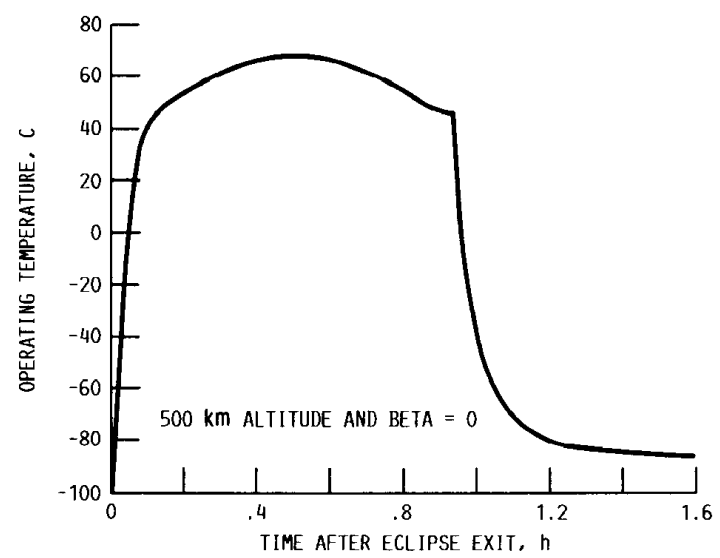

FIGURE 3. - PV ARRAY OPERATING TEMPERATURE.
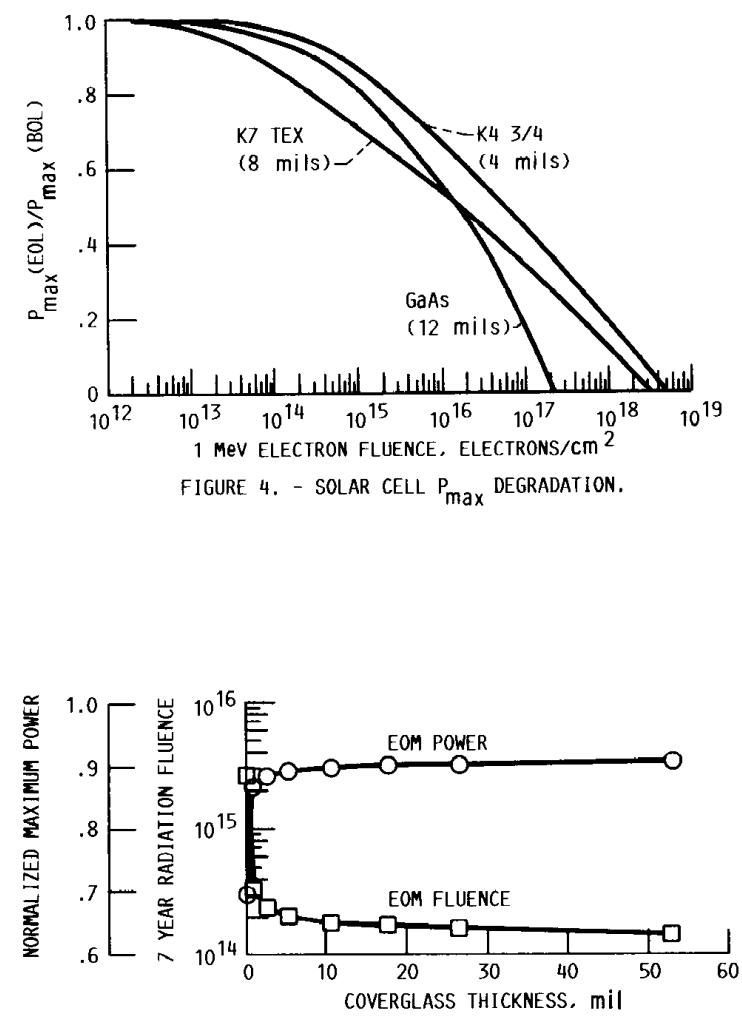

FIGURE 5, - EFFECT OF COVERGLASS THICKNESS ON PV ARRAY (SI) DEgRADATION, MISSION 4. (1 MeV ELECTRON EQUIVALENCE) 


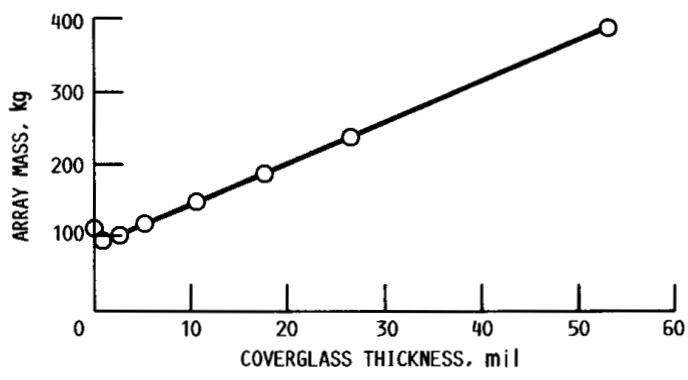

FIGURE 6, - EFFECT OF COVERGILASS THICKNESS ON PV ARRAY (SI) MASS, MISSION 4 .

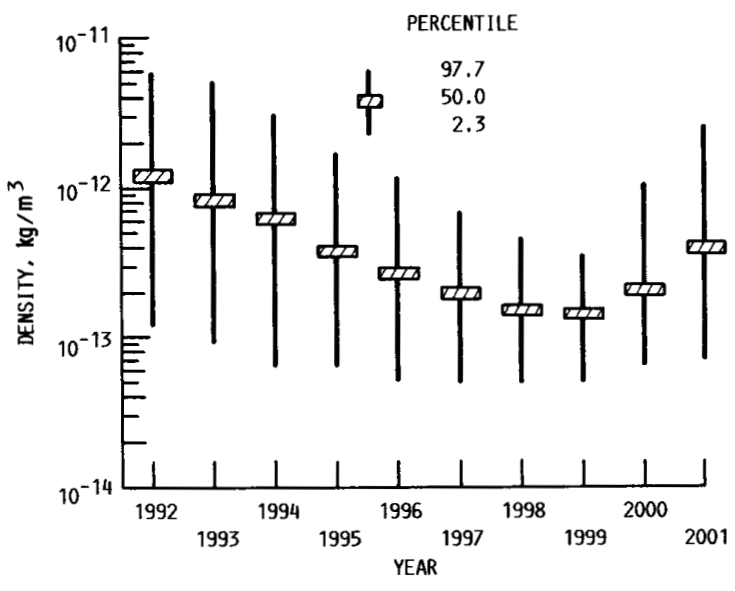

FIGURE 7. - ATMOSPHERIC DENSITY PREDICTIONS, $500 \mathrm{~km}$ ALTITUDE AND 28.5 DEGREE INCLINATION.

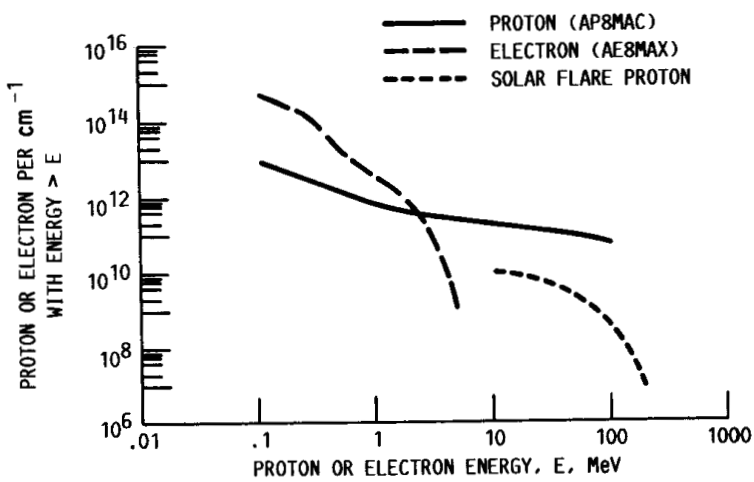

FIGURE 8. - INTEGRAL TRAPPED ELECTRON AND PROTON AND SOLAR FLARE PROTON FLUENCE, MISSION $3(1200 \mathrm{~km}$. 60 DEGREE, AND 7 YEARS).

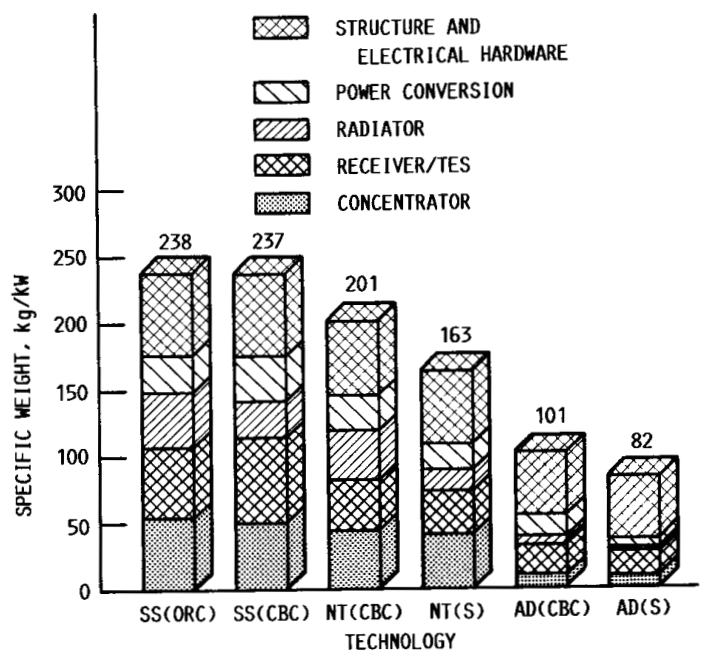

FIGURE 9. - SPECIFIC WEIGHT BREAKDOWN VERSUS TECHNOLOGIES, SD.

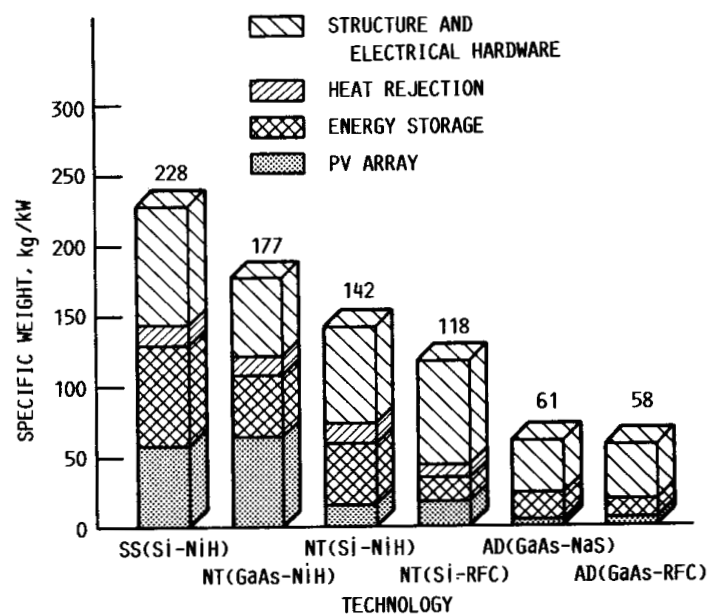

FIGURE 10. - SPECIFIC WEIGHT BREAKDOWN VERSUS TECHNOGIES, PV. 